\title{
THE MODEL OF LAW ENFORCEMENT FOR JUVENILE DELINQUENT IN THE PROCESS OF INVESTIGATION BASED ON LAW NUMBER 11 YEAR 2012 CONCERNING JUVENILE JUSTICE SYSTEM ${ }^{\Omega}$
}

\author{
Hamidah Abdurrachman, Fajar Ari Sudewo and Dyah Irma Permanasari \\ Law Faculty Universitas Pancasakti Tegal \\ E-mail: hamidah.azzahara@gmail.com
}

\begin{abstract}
This study analyses the application of law enforcement model on juvenille offender before the law. Especially, in investigations according to Act number 11, 2012 about Juvenille Penal Court system in Central Java. Since the act has been formally implemented, the penal court elements have been given two years time to prepare strategies in handling juvenille offender through Diversion with Restorative Justice approach. However, the implementation of Diversion needs several infrastructures such as Juvenille Investigators, Diversion Standard of Operation (SOP), and a proper place for investigating children and mediation process, including children cells. This is an empirical study with primary and secondary sources, including analysis of Acts, literature review, and expert review. The data analysis will be done qualitatively.
\end{abstract}

Keywords: juvenille offender, restorative justice, law enforcement

\section{Abstrak}

Penelitian ini mengkaji penerapan model penegakan hukum anak yang berhadapan dengan hukum dalam proses penyidikan berdasarkan Undang-Undang Nomor 11 Tahun 2012 Tentang Sistem Peradilan Pidana Anak di wilayah Kepolisian Daerah Jawa Tengah. Sejak ditetapkan Undang-Undang Nomor 11 Tahun 2012 Tentang Sistem Peradilan Pidana Anak, elemen sistem peradilan pidana khususnya Kepolisian, diberi waktu 2 tahun untuk persiapan penanganan anak yang berhadapan dengan hukum melalui diversi dengan pendekatan restoratif justice. Penerapan diversi membutuhkan sarana prasarana pendukung seperti penyidik anak, SOP diversi, ruangan layak anak baik untuk pemeriksaan, mediasi dan ruang tahanan anak. Jenis penelitian ini adalah empiris, dengan menggunakan sumber data primer dan sekunder meliputi perundang-undangan, literatur dan doktrin. Analisis data dilakukan secara kualitatif.

Kata kunci: anak berkonflik dengan hukum, keadilan restoratif, penegakan hukum

\section{Introduction}

The enactment of Law Number 11 Year 2012 concerning Juvenile Justice System brings a fundamental changes, which is the use restorative justice approach through diversion. Mentioned in Article 1, Number 6, restorative justice is the completion of the criminal case involving the perpetrator, the victim, the perpetrator's family/victim, and other relevant parties that work together to find a fair settlement that emphasizes on restoring back to the original condition, and not retaliation. Restorative justice can be called a model of a new paradigm of law enforcement to respond the dissatisfaction on the criminal justice system that put more emphasis on the process of law. "The practice of law by law enforcement that occurred in Indonesia always refers to the legism thinking as the main characteristic of legal positivism. In this case, the legal point of view is seen by the legislation telescope that is applicable to later judge the incident happening". ${ }^{1}$ Injustice occurring in the handling of law

$\Omega$ This research is sponsored by Indonesian Directorate of Higher Education with contract agreement number: 006/SP2H/PL/Dit.Litabmas, dated February 5th 2015.

A. Sukris Sarmadi, "Membebaskan Positivisme Hukum ke Ranah Hukum Progressif", Jurnal Dinamika Hukum, Vol. 12 No. 2, May 2012, Purwokerto: Faculty of Law Universitas Jenderal Soedirman, page 331. 
by law enforcement is a misnomer because the real form of the law itself purposes a justice (gerechtigheit). ${ }^{2}$

Restorative Justice approach in Law Number 11 Year 2012 concerning Juvenile Justice System is a concept that responds the development of the justice system emphasizing on the needs for community involvement and victims that were excluded by mechanisms in the criminal justice system nowadays. ${ }^{3}$ Restorative justice changes the interaction between the perpetrator with the victim as opposite to being cooperative patterns or integration and the issue of crime as an act by the perpetrator against individuals or communities and not to the state. There are some basic principles of restorative justice related to the relationship between crime, perpetrators, victims, society and the state: first, the crime was placed as the symptoms that are part of social action and not just a violation of criminal law; second, restorative Justice is a theory of criminal justice that focuses on a vision that sees the crime was an act by the perpetrator to another person or the community rather than to the state; and third crime is seen as actions that harm people and damage social relations, fourth the appearance of the restorative justice idea is as a critique for the application of the criminal justice system with imprisonment that is not effective to solve the social conflicts. Identification of some characteristic/typical of programs or results (outcomes) of restorative justice including: victim offender mediation (to mediate between perpetrators and victims); conferencing (bringing the parties); circles (mutual support); victim assistance (to help victims); ex offender assistance (helping people who have committed crimes); restitution (give compensation/heal); community service. ${ }^{4}$

2 Agus Raharjo and Angkasa, "Professionalisme Polri dalam Penegakan Hukum", Jurnal Dinamika Hukum, Vol. II No. 3, September 2011, Purwokerto: Faculty of Law Universitas Jenderal Soedirman, page 385.

3 Wahyudi and Deni, "Perlindungan Terhadap Anak Yang Berhadapan dengan Hukum Melalui Pendekatan Restorative Justice", Jurnal Ilmu Hukum, Vol. 6 No. 1, February 2015 Edition, Jambi: Universitas Jambi page 146.

4 Kuat Puji Prayitno, "Restorative justice untuk Peradilan di Indonesia (Perspektif Yuridis Filosofis dalam Pene-
Viewed from the development of criminalistics and modern criminal properties, has long been introduced and developed what is called the rapprochement Perpetrators Victims or "Doer-Victims" Relationship, replacing the act or the perpetrator approaches or "daad-dader straftecht". There are three aspects of our approach to build a legal system in order to modernize and update the law, which is structure, substance and legal culture in which all of those are eligible to run integrally, simultaneously and parallelly. ${ }^{5}$ From the substance, the reality of our positive legal system is an open system, so its enabling a change and development of the existing legal system. ${ }^{6}$

The facts presented by the Indonesian Child Protection Commission (KPAl) in 2014 there were 7,000 children who were detained in the police level. Handling of children in conflict with the law is still followed the procedures based on KUHAP positive law without considering the interests of the child. They are treated like adults, they often got a violence and abuse, they are in the custody of adult.

Since the set of Law Number 11 Year 2012 concerning Juvenile Justice System in 2012, elements of the criminal justice system such as police, prosecutors, courts and correctional given two years to prepare for implementing. Especially the police who handle children in conflict with the law carried out by the Women and Children's unit under the General Crimes Unit. Application of Law Number 11 Year 2012 concerning Juvenile Justice System needs a variety of preparations such as the availability of children investigator, SOP techni-

gakan hukum In Conreto)", Jurnal Dinamika Hukum, Vol. 12 No. 3 September 2012, Purwokerto: Faculty of Law Universitas Jenderal Soedirman, page 411

5 Daniswara K. Harjono, "Pengaruh Sistem Hukum Common Law Terhadap Hukum Investasi Dan Pembiayaan Di Indonesia" Lex Jurnalicia, Vol. 6 No.3 August 2009 Edition, Jakarta: Universitas Esa Unggul, page 182.

6 Doni Yusra, "Politik Hukum Hakim Dibalik Penemuan Hukum (Rechtsvinding) Dan Penciptaan Hukum (Rechtsschepping) Pada Era Reformasi Dan Transformasi”, Lex Jurnalicia, Vol. 10 No. 2, August 2013, Jakarta: Universitas Esa Unggul, page 67.

7 Wahyu Syahputra, "Duh, Sudah Ada 7 Ribu Anak dalam Proses Hukum di Indonesia", Republika, $16^{\text {th }}$ of June 2014. 
cally set the implementation of diversion, infrastructure such as eligible room for children both for inspection and mediation, and also space juveniles which is nowadays still rare.

Research on Law Enforcement models of children in conflict with the law will assess the implementation of Law Number 11 Year 2012 concerning Juvenile Justice System, especially the model of restorative justice through the diversion in the region of Central Java Regional Police.

\section{Hypothesis}

The research found two problems which are the application of law enforcement model for juvenile delinquent in the investigation process based on Law Number 11 Year 2012 concerning Juvenile Justice System and obstacle for police in the implementation of Law Number 11 Year 2012 concerning Juvenile Justice System.

\section{Research Methods}

This methods of research is empirical legal research. The data used is the Law of Juvenile Justice System, KUHAP, and secondary legal materials including literature and doctrine or scholars opinion. Collection of the data through documents and interviews conducted openly with the Chief of Investigation Unit and Police Investigators in the Central Java Police Jurisdiction. Data analysis is conducted qualitatively that outlines descriptive-analysis and prescriptive.

\section{Discussion}

Juvenile Justice System is a same definetion with some institutions that join as a member of the court, which includes the police, prosecutors and lawyers, supervisory institutions, children detention centers and facilities coaching. ${ }^{8}$ Mulyadi said, the criminal justice system is a judicial network that utilizes criminal law as a primary infrastructure, both ma-

8 Setya Wahyudi, "Penegakan Peradilan Pidana Anak dengan Pendekatan Hukum Progresif dalam Rangka Perlindungan Anak", Jurnal Dinamika Hukum, Vol. 9 No. 1 January 2009, Purwokerto: Faculty of Law Universitas Jenderal Soedirman, page 30-31 terial criminal law, the formal criminal law and criminal implementation law. ${ }^{9}$ According to Mardjono Reksodiputro, the meaning of system in the criminal justice system is crime control system, consisting of police institutions, prosecutors, courts and prisons, so that these components can be set as parts of the criminal justice system. Law Number 11 Year 2012 concerning Juvenile Justice System in Article 1 paragraph (1) states that the definition of the Juvenile Justice System is the whole settlement process of children in conflict with the law starting from the investigation process to supervision process after serving a criminal.

In this relationship, the implementation of the Juvenile Justice System, the police perceived as the most dominant institution in determining the success of law enforcement with restorative justice models. Fetri A. Tarigan ${ }^{10}$ said the diversion profits is done on the investigation process, which is explaining that the polices are the only one law enforcement agent that reaches wider scope so that structurally has the closest and most accessible position to the public; institutionally there is so much police officers, although not all members of the Police have committed yet to seriously deal with cases of children; because the polices are the first law enforcement officers engaged in the criminal justice process so that the diversion at the police level has mean to give a guarantee for children as soon as possible to be prevented a crash with the criminal justice process. Through the mediation penal process justice so that can be resulting a summit higher justice because of there is an agreement of the parties involved in the criminal case is between the perpetrator and the victim. Victims and perpetrators are expected to seek and achieve a solution as well as the best alternative to sol-

$9 \quad$ Ahmad Fauzi, "Analisis Yuridis Terhadap Upaya Hukum Luar Biasa Peninjauan Kembali (PK) Oleh Jaksa Dalam Sistem Hukum Acara Pidana Indonesia" Jurnal Ilmu Hukum, Vol. 4 No. 2 February-July 2014, Riau: Laboratiorium Hukum Faculty of Law Universitas Riau, page 139

10 Fetri A.Tarigan, "Upaya Diversi Bagi anak Dalam Proses Peradilan", Jurnal Lex Crimen, Vol IV No. 5, July 2015, Manado: Faculty of Law Universitas Sam Ratulangi, page 106. 
ve the case. The implications of this achievement both parties can apply for the compensation offered, agreed and negotiated between them together so that the solution reached is a "win-win" solution. ${ }^{11}$ "However, diversion can only be done with the permission of the victims and the families of the victim, as well as the willingness of the offender and his family. Attempts to resolve the matter outside of court should take precedence; even the mediation process was still possible even though the matter had been entered in court". ${ }^{12}$

Diversion programs should be able to develop the attitudes of children to respect others. After going through this program the children are expected to has the ability to understand the mistake and to not repeat their actions again. ${ }^{13}$ So that, the law enforcement at all levels shall prioritize the settlement out of court even diversion may also be made by public after obtaining permission from both parties first ${ }^{14}$. The diversion usually requires an admission of guilt from the perpetrator and is accompanied by a requirement to fulfill a condition. Diversion essentially can be placed at every stage in the judicial process, including at the arrest, prosecution, examination in court, sentencing, the result can be either a suspension or determined the case from formal court processes $^{15}$.

The signs given by Law Number 11 Year 2012 concerning Juvenile Justice System, Arti-

11 Ainal Mardiah dkk, "Mediasi Penal Sebagai Alternatif Model Keadilan Restoratif Dalam Pengadilan Anak" Jurnal Ilmu Hukum, Vol. 1, No. 1, August 2012, Banda Aceh: Pascasarjana Universitas Syiah Kuala, page 6.

12 Loura Hardjaloka, "Criminal Justice System of Children: an overview Restorative Justice Concept in Indonesia and Other Countries", Jurnal Dinamika Hukum, Vol 15 No 1 , January 2015, page 76 .

13 Olvina Kartika Mament, "Peran Pasal 2 Undang-Undang Nomor 11 Tahun 2012 Tentang Sistem Peradilan Pidana Anak Terhadap Anak Yang Berkonflik Dengan Hukum", Lex Crimen, Vol. 4 No. 2 April 2015, Manado: Faculty of Law Universitas Sam Ratulangi, page 146

14 Septa Candra, "Restorative Justice: Suatu Tinjauan terhadap Pembaharuan Hukum Pidana di Indonesia", Jurnal Rechtsvinding Vol 1 Nomor 2, August 2013, Jakarta: Badan Pembinaan Hukum Nasional, page 274.

15 Herlyanty Yuliana Anggraeny Bawole,"Implementasi Pendekatan Restoratif dalam Penanggulangan Kejahatan Korporasi menurut Sistem Hukum Pidana di Indonesia", Lex Crimen, Vol 3 No. 3 May-July 2014, Manado: Faculty of Law Universitas Sam Ratulangi, page 95 cle 8 , paragraph (1) the process of diversion is done through discussion involving a child and a parent/guardian, victim and/parent/guardian, the supervising social, and social workers/professionals. In Article 9 Paragraph (1) shall consider the categories of offenses; age of children; the research community of Bapas; support from family and community environment. Article 9 Paragraph (2) formulates that a diversion agreement must be approved by the victim and/or child's family victims as well as the willingness of the child and the family.

Diversion agreement made by the investigator on the recommandation of Supervising Community may includes, give the form of indemnification in case there is a victim; medical and psychosocial rehabilitation; handover to the parents/trustees; participation in education or training in an educational institution or LPKS maximally about three months, or community service longest for three months. In Article 11 of the diversion agreement can be formulated: have a peace with or without compensation; handover to parents/trustees; participation in education or training in an educational institution or LPKS later than three months, or community service. Affirmed in Article 13 that the juvenile justice process is continued if diversion process does not create any agreement, or diversion agreement is not implemented. Schematic model of law enforcement for juvenile delinquent through the diversion can be seen in the following picture 1 .

Survey shows that the Law Enforcement with Restorative Justice Model through Diversion has been conducted for children in conflict with law. The survey was conducted in 6 (six) Police Resort (Polres) in Central Java Police area which includes Pati Police Resort which represented former Pati residency, Purworejo Police Resort which represented former Kedu residency, Semarang City Police Resort (Polrestabes) which represented former Semarang residency, Banyumas Police Resort which represented former Banyumas residency, Surakarta Police represented Surakarta residency and Tegal Police Resort which represented former Pekalongan residency. 


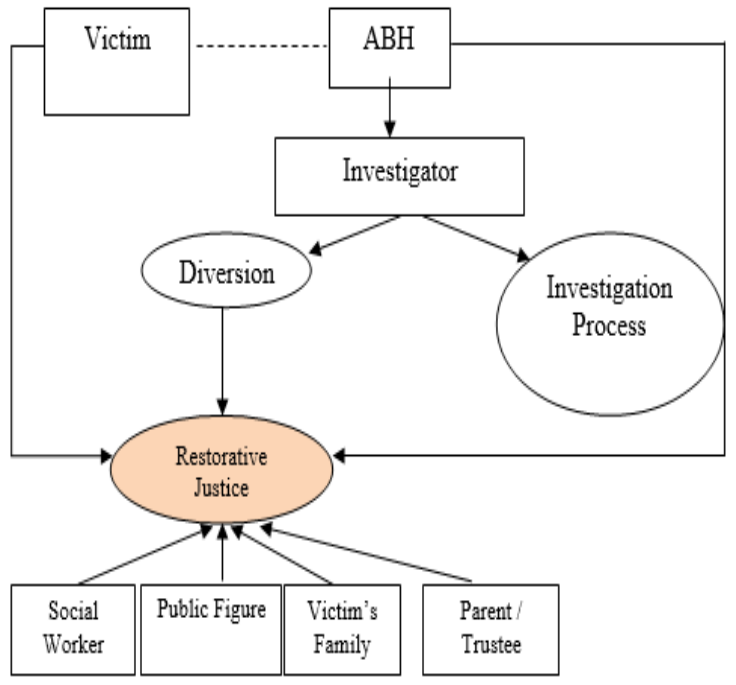

Picture 1

Settlement Model of juvenile delinquent through the Diversion with Restorative Justice approach

Handling of Juvenile who has conflict with the law in the Central Java Police can be summarized as follows:

Table 1. Handling of Juvenile who dealing to the Law on the Central Java Police

\begin{tabular}{|c|c|c|c|c|c|}
\hline \multirow{2}{*}{$\begin{array}{c}\text { Police } \\
\text { Resort }\end{array}$} & \multirow{2}{*}{$\begin{array}{c}\text { Juvenile } \\
\text { who } \\
\text { dealing } \\
\text { with }\end{array}$} & \multicolumn{4}{|c|}{ Handling Method } \\
\cline { 3 - 6 } & 8 & Process & $\%$ & Diversion & $\%$ \\
\hline Pati & 8 & 5 & 27,5 & 3 & 72,5 \\
\hline Purworejo & 45 & 38 & 84,5 & 7 & 15,5 \\
\hline Tegal & 16 & 6 & 37,5 & 10 & 62 \\
\hline Semarang & 55 & 35 & 44,5 & 30 & 55,5 \\
\hline Banyumas & 54 & 16 & 29,6 & 38 & 70,4 \\
\hline Surakarta & 12 & 0 & 0 & 12 & 100 \\
\hline
\end{tabular}

From the table above, the Law Enforcement Model by restorative justice approach through Diversion has been done, although it seems conducted formally. But this effort is not always successful because an agreement between the parents offender with the victim's family is not reached. As a result, these cases are continued into the investigation process. For the example, in the Purworejo Police Resort from 45 cases handled, only $15.5 \%$ of diversion was successful. While the Surakarta Police Resort $100 \%$ successfully implements diversion. The result of diversion agreement prefers to bring back the offenders to their parents. This result raises an anxiety that the crimes will be repeated because there is no further development of juvenile offenders.

The offenders' age is in the range between 13 to 18 years, while the dominant crimes committed are physical abuse, mayhem, theft with violence/weighting, beatings, sexual abuse, sexual intercourse and rape. Juvenile who continued to the criminal proceedings, in an effort to forcible detention delivered to prisons because almost all of the police office in Indonesia do not have room custody of juvenile.

So far, diversion implementation virtually only focuses on the offender, in this case juvenile. On the other hand, there is a victim of crime that can not be ignored. All the time, state represents the public interest by punishing the offender (the deterrent effect) and then rehabilitation, but has not touched the interests of the victim, the state seemed to neglect the needs of victims. Guilty perpetrators are actually jailed on state costs while the victim after the case is completed no longer be a concern. For this reason the public access in the Indonesian criminal justice system should be improved, especially law enforcement officials should be aware of this gap. One form public access is in the form of a statement of suffering of victims to the judges (victim impact statement). Through this statement, victims can convey exactly what they want from the proceedings aimed at seeking justice. ${ }^{16}$

Law enforcement must have a sensitivity to the suffering of victims which is not only seen the Diversion as a formality. Diversion presents a different overview from the perspective of the victim, as stated by J.J. Choi et.al. ${ }^{17}$

"A few victims felt that they were coerced into mediation. For example, some felt that they had been led to believe that they had to go through the program to get money back. Lastly, some victims reported that they felt re-victimized by the experience. Of all of these findings,

16 Kuat Puji Prayitno, op-cit, page 418-419.

17 J.J. Choi et.al, "Review on research on Victims Experiences in Restorative Justice", Children \& Youth Services Review, Vol. 34, Issue 1, January 2012, Page 3542. 
the last one is the most unfortunate because it is directly contrary to the underlying theory, values, principles, and outcomes believed to be paramount in RJ. Umbreit and colleagues have continually reported similar issues and concerns in their subsequent work."

That shows the reason why in some cases that implemented the diversion has failed because the victim's parents assumed that the peace efforts undertaken by the police only aims to release the offender from legal process and victims do not get satisfaction on their misery. Implementation of restorative justice through diversions does not stop at the process of legislation, but it takes a further step in implementing the provisions of Law No. 11 of 2012 on the Criminal Justice Juvenile Systems, through the regulation establishment which technically regulates the implementation of Diversions. Likewise required the construction of infrastructure and improvement of law enforcement officials so that the implementation restorative justice concept through diversion can be implemented optimally. ${ }^{18}$

Likewise, it is necessary to have socialization to public regarding to the importance of diversion in the implementation criminal justice juvenile system as a means of educating ju-venile who have already committed a crime/ offense to obey the law. ${ }^{19}$ Police obstacle in the implementation of Law No. 11 of 2012 on the Criminal Justice Juvenile System can be seen in several ways.

\section{Police Investigators}

Article 26 paragraph (1) of Law No. 11 Year 2012 formulated that Investigation on the case of juvenile is conducted by the investigator based on the Decree of the Chief of Police

18 Yutirsa Yunus, “Analisis Konsep Restorative justice melalui sistem Diversi dalam Sistem Peradilan Pidana Anak di Indonesia", Jurnal Rechtsvinding, Vol. 2 No. 2 August 2013, Jakarta: Badan Pembinaan Hukum Nasional, page 244.

19 Nurhidayati, "Peradilan Pidana Anak dengan Pendekatan Restorative Justice dan Kepentingan Terbaik Bagi Anak", Ragam, Jurnal Pengembangan Humaniora, Vol. 13 No. 2 August 2013, Semarang: Universitas Diponegoro, page 151 . or other officials appointed by the Chied of Police. Article 26 paragraph (3) set out the conditions that must be fulfilled are experienced investigator; be passionate, attention, dedication and understanding the problems of children; followed technical training on juvenile justice.

Results of research on the availability of investigators, as follows:

Table 2. Juvenile Investigators Data

\begin{tabular}{|c|l|c|c|}
\hline No & Police Resort & $\begin{array}{c}\text { Number of } \\
\text { Investigator } \\
\text { Juvenile } \\
\text { Criminal Justice }\end{array}$ & $\begin{array}{c}\text { Number of } \\
\text { Juvenile } \\
\text { Investigator }\end{array}$ \\
\hline 1 & Pati & 6 & 0 \\
\hline 2 & Purworejo & 7 & 1 \\
\hline 3 & Kota Teal & 5 & 1 \\
\hline 4 & Semarang & 13 & 3 \\
\hline 5 & Banyumas & 7 & 2 \\
\hline 6 & Surakarta & 8 & 2 \\
\hline
\end{tabular}

Table 2 shows that the number of investigators of juvenile is still less. Even in Pati Police Resort from six investigators in Juvenile Criminal Justice Unit no one has to follow a special vocational education handling to juvenile delinquent. Nationally currently there are 400 Investigators juvenile from 3000 the expected target. This is due to every year the Police Headquarters are only able to train 60 investigators annually. Explanation of Deputy Chief of State Police School Purwokerto (SPN Purwokerto), ${ }^{20}$ in 2015 only educates 25 from Police Resort to Juvenile Criminal Justice of vocational education. The absence of Juvenile Investigators understanding and mastering the technique of handling the juvenile in conflict with the law properly, causes firstly inflicting interpretation in the application of Diversion; Secondly case handling juvenile except who has been a concern public is not a priority, so that the diversion destination which is "goal" of Law No. 112012 on Juvenile Criminal Justice System is not reached.

\section{The Deadline}

In the juvenile justice system in Law No. 11 Year 2012 on each level are given time seven (7) days obliged to implement the diversion which is given to investigators, prosecutors and

20 Interview with AKBP Eko Nugroho, Monday, $21^{\text {st }}$ of December 2015 in SPN Purwokerto. 
judges. If that fails, or in other words the diversion at each level do not succeed with this deadline expires then the process will keep running starting from investigation, prosecution through the court process. This deadline might say a major obstacle considering the implementation of the Diversion involves several parties, such as family, correctional centers, volunteers etc. Many requests coming to Regulatory Body (Bapas) cause difficulty to fulfill the request of police by the deadline.

Investigator of Institute For Criminal Justice Reform (ICJR) Erasmus A.T Napitupulu revealed eight recommendations in order to make implementation of Juvenile Criminal Justice System Law run effective. First, ICJR urges the Government to speed up the preparation of several draft government regulation related Juvenile Criminal Justice System laws, and be open also participatory. Second, the need for improvement the resource, infrastructure and strengthening the capacity of officials associated public protection tutors Community as public research maker. Investigators, Public Prosecutor and Judge, also need to be given an understanding of Social Research. Third, ICJR argues that the number of mentoring on juvenile needs to be multiplied, including their access to lawyers. Obligation to accompany the juvenile in criminal proceedings should not be reduced. Fourth, ICJR recommends that the number of district courts which has a special courtroom for children must be increased in quantity and quality. Fifth, ICJR proposes that training related to the implementation of SPPA Law (UU SPPA) should be multiplied specifically for police, prosecutors, and judges. Sixth, creation of internal regulation or SOP both for investigators or Prosecutor regarding to guidelines for the handling of juvenile cases and also preparing the matters related to the implementation of diversion as a new regulation. Seven$t h$, the government needs to increase the number of Institutions Development of Special Children (LPKA) and Institution of Child Placement Meantime (LPAS). It should be planning more serious. Eighth, the Supreme Court and / or the Ministry of Justice and Human Rights need to regulate properly related to the complaint mechanism and supervision of forceful measures in juvenile, particularly related to arrest, detention, and searches. ${ }^{21}$

\section{Conclusion}

It has been done the Law Enforcement with the Restorative Justice Model through $\mathrm{Di}$ version, but these efforts are not always successful because an agreement between the parents offender with the victim's family is not reached. Central Java police, from 200 cases of juvenile in conflict with the law are resolved through diversion path is 100 cases or $50 \%$, whereas 100 juvenile cases processed to the process of investigation.

Diversion implementation obstacles are the limited number of juvenile investigators, the infrastructure has not been fulfilled, the deadline to complete diversion involving multiple parties such as correctional centers, public figure and families of victims are lack.

\section{Suggestion}

As a suggestion, the Government should implement the provisions of article 92 of Law Number 11 Year 2012 concerning Juvenile Justice System that provides education and training for law enforcement and other related parties in an integrated manner. As well, the Police Leader should give attention in handling children in conflict with the law by providing support in the fulfillment of infrastructure.

\section{References}

Bawole, Herlyanty Yuliana Anggraeny. "Implementasi Pendekatan Restoratif dalam Penanggulangan Kejahatan Korporasi Menurut Sistem Hukum Pidana Di Indonesia". Lex Crimen, Vol 3 No. 3 May-July 2014. Manado: Faculty of Law Universitas Sam Ratulangi;

Candra, Septa. "Restorative Justice: Suatu Tinjauan Terhadap Pembaharuan Hukum Pi-

21 Erasmus A.T Napitupulu, "Prospek Implementasi Sistem Peradilan Pidana Anak di Indonesia", available at www. beritasatu.com/.../226158-ini-8-rekomendasi-agarimplementasi-uu-sppa-efektif, $18^{\text {th }}$ of November 2014, accessed on 22 ${ }^{\text {nd }}$ of December 2015. 
dana di Indonesia". Jurnal Rechtsvinding, Vol 1 No. 2, August 2013. Jakarta: Badan Pembinaan Hukum Nasional;

Choi, J.J.et.al. "Review on research on Victims Experiences in Restorative Justice". Children \& Youth Services Review. Volume 34. Issue 1. January 2012;

Fauzi, Ahmad. "Analisis Yuridis terhadap Upaya Hukum Luar Biasa Peninjauan Kembali (PK) oleh Jaksa dalam Sistem Hukum Acara Pidana Indonesia". Jurnal Ilmu Hukum. Vol. 4 No. 2 February-July 2014. Riau: Laboratiorium Hukum, Faculty of Law, Universitas Riau;

Hardjaloka, Loura. "Criminal Justice system of Children: an overview Restorative Justice Concept in Indonesia and Other Countries". Jurnal Dinamika Hukum, Vol 15 No 1. January 2015. Purwokerto: Faculty of Law, Universitas Jenderal Soedirman;

Harjono, Daniswara K. "Pengaruh Sistem Hukum Common Law terhadap Hukum Investasi dan Pembiayaan di Indonesia". Lex Jurnalicia Vol. 6 No.3 August 2009. Jakarta: Universitas Esa Unggul;

Mament, Olvina Kartika. "Peran Pasal 2 Undang-Undang No. 11 Tahun 2012 Tentang Sistem Peradilan Pidana Anak Terhadap Anak yang Berkonflik dengan Hukum". Lex Crimen, Vol. 4 No. 2 April 2015. Manado: Faculty of Law Universitas Sam Ratulangi;

Mardiah, Ainal dkk. "Mediasi Penal Sebagai Alternatif Model Keadilan Restoratif Dalam Pengadilan Anak". Jurnal Ilmu Hukum, Vol. 1. No. 1. August 2012. Banda Aceh: Pascasarjana Universitas Syiah Kuala;

Napitupulu, Erasmus A.T. “Prospek Implementasi Sistem Peradilan Pidana Anak di Indonesia". available at www.beritasatu. com/.../226158-ini-8-rekomendasi-agarimplementasi-uu-sppa-efektif. $18^{\text {th }}$ of November 2014. accessed on $22^{\text {nd }}$ of December 2015.

Nurhidayati. "Peradilan Pidana Anak dengan Pendekatan Restorative Justice dan Kepentingan Terbaik Bagi Anak". Ragam. Jurnal Pengembangan Humaniora, Vol. 13 No. 2 August 2013. Semarang: Universitas Dipenogoro;

Prayitno, Kuat Puji. "Restorative Justice untuk Peradilan di Indonesia (Perspektif Yuridis
Filosofis dalam Penegakan Hukum In Conreto)". Jurnal Dinamika Hukum, Vol. 12 No. 3 September 2012. Purwokerto: Faculty of Law Universitas Jenderal Soedirman;

Raharjo, Agus and Angkasa. "Professionalisme Polri Dalam Penegakan Hukum". Jurnal Dinamika Hukum. Vol. II No. 3. September 2011. Purwokerto: Faculty of Law Universitas Jenderal Soedirman;

Sarmadi, A. Sukris. "Membebaskan Positivisme Hukum ke Ranah Hukum Progressif". Jurnal Dinamika Hukum. Vol. 12 No. 2. May 2012. Purwokerto: Faculty of Law Universitas Jenderal Soedirman;

Syahputra, Wahyu. "Duh,Sudah Ada 7 Ribu Anak dalam Proses Hukum di Indonesia". Republika. $16^{\text {th }}$ of June 2014;

Tarigan, Fetri A. "Upaya Diversi bagi anak dalam Proses Peradilan". Jurnal Lex Crimen, Vol IV No. 5. July 2015. Manado: Faculty of Law Universitas Sam Ratulangi;

Wahyudi \& Deni. "Perlindungan Terhadap Anak Yang Berhadapan dengan Hukum Melalui Pendekatan Restorative Justice". Jurnal Ilmu Hukum, Vol. 6 No. 1. February 2015. Jambi: Universitas Jambi;

Wahyudi, Setya. "Penegakan Peradilan Pidana Anak dengan Pendekatan Hukum Progresif dalam Rangka Perlindungan Anak". Jurnal Dinamika Hukum, Vol. 9 No. 1 January 2009. Purwokerto: Faculty of Law Universitas Jenderal Soedirman;

Yunus, Yutirsa. “Analisis Konsep Restorative Justice melalui Sistem Diversi dalam Sistem Peradilan Pidana Anak di Indonesia". Jurnal Rechtsvinding Vol. 2 No. 2 August 2013. Jakarta: Badan Pembinaan Hukum Nasional;

Yusra, Doni. "Politik Hukum Hakim Dibalik Penemuan Hukum (Rechtsvinding) dan Penciptaan Hukum (Rechtsschepping) pada Era Reformasi dan Transformasi". Lex Jurnalicia, Vol. 10 No. 2, August 2013. Jakarta: Universitas Esa Unggul; 